\title{
GAMBARAN FATIGUE PADA PASIEN KANKER POST KEMOTERAPI
}

\author{
Dahlia $^{1}$, Darwin Karim² ${ }^{2}$, Siti Rahmalia Hairani Damanik ${ }^{3}$ \\ ${ }^{1,2,3}$ Fakultas Keperawatan Universitas Riau \\ Fakultas Keperawatan Universitas Riau Jalan Pattimura No 9 Gedung G Pekanbaru Riau \\ Kode Pos 28131 Indonesia \\ email dahliaafinah@gmail.com
}

\begin{abstract}
Abstrak
Kemoterapi adalah salah satu pengobatan kanker untuk membunuh sel-sel kanker, mencegah pertumbuhan dan penyebaran sel-sel abnormal yang tidak terkendali yang cenderung menyerang jaringan di sekitarnya dan menyebar ke organ lain. Efek samping kemoterapi seperti mual muntah, anemia, dan masalah tidur dapat menyebabkan fatigue. Penelitian ini bertujuan untuk mengetahui identifikasi fatigue pada pasien kanker dengan post kemoterapi. Metode yang digunakan pada penelitian ini adalah deskripstif sederhana. Penelitian ini dilakukan di RSUD Arifin Achmad Pekanbaru pada 7-16 Mei 2018 dengan melibatkan 144 responden yang diambil dengan teknik purposive sampling. Data dikumpulkan dengan mengguanakan kuisioner yang telah diuji validitas dan reabilitas. Kuisioner adalah Piper Fatigue Scale. Data dianalisis dengan analisis univariat untuk menentukan distribusi frekuensi. Hasil penelitian ini menunjukkan bahwa responden pada fatigue tingkat ringan sebanyak 11 orang $(7,6 \%)$, tingkat sedang sebanyak 72 orang (50\%) dan tingkat berat sebanyak 61 orang $(42,4 \%)$. Hasil penelitian ini diharapkan dapat memberikan identifikasi kepada profesi perawatan kesehatan mengenai fatigue pada pasien kanker dengan post kemoterapi untuk dapat lebih meningkatkan asupan nutrisi dan aktivitas yang seimbang pada pasien sehingga derajat fatigue dapat menurun atau tidak bertambah parah.
\end{abstract}

Kata kunci: Fatigue, Kanker, Kemoterapi

\begin{abstract}
Chemotherapy is a cancer treatment to kill cancer cells, inhibit growth and spread of abnormal cells that are uncontrolled which tends to attack surrounding tissue and spread to other organs. The side effects of chemotherapy such as nausea, vomiting, anemia, and sleep problems can cause fatigue. This study aims to determine the identification of fatigue in cancer patients with post chemotherapy. The method used in this study is a simple description. This research was conducted at Arifin Achmad Hospital in Pekanbaru on May 7-16, 2018 involving 144 respondents taken by purposive sampling technique. Data was collected by using a questionnaire that have tested validity and reliability. The questionnaire is the Piper Fatigue Scale. Data was analyzed by univariate analysis to determine the frequency distribution. The result of this study showed that respondents in mild level of fatigue 11 people (7.6\%), moderate level 72 people (50\%) and severed level 61 people $(42.4 \%)$. The results of this study are expected to provide identification to health care profession
\end{abstract}


Dahlia $^{1}$, Darwin Karim ${ }^{2}$, dan Siti Rahmalia Hairani Damanik ${ }^{\mathbf{3}}$, Gambaran Fatigue pada Pasien Kanker Post Kemoterapi

abaout fatigue cancer patients with post chemotherapy to be able to improve of intake nutritional and balanced activity in patients so that degree of fatigue can decrease or not get worse..

Keywords: Cancer, Chemotherapy, Fatigue

\section{PENDAHULUAN}

Kanker adalah sekelompok penyakit yang ditandai dengan pertumbuhan dan penyebaran sel abnormal yang tidak terkontrol (American Cancer Society, 2018). World Health Organization (2018) menyatakan bahwa angka kanker sudah mencapai 18,1 juta kejadian kanker global dan 9,6 juta kematian akibat kanker di dunia. Prevalensi kanker pada semua tingkat usia di Indonesia pada tahun 2013 sebesar 1,4\% atau diperkirakan sekitar 347.792 orang (Kementerian kesehatan RI, 2015).

Penyakit kanker memiliki dampak terhadap fisik dan psikologis. Menurut Kashani, Vaziri, Akbari, Jamshidifar, dan Sanaei (2014) mengatakan meskipun kini pendeteksian kanker sudah berkembang dengan pesat, namun insidensi kanker merupakan stressor paling berpengaruh bagi penderitanya dan hal ini berhubungan terhadap persepsi masyarakat mengenai penyakit kanker yang identik dengan kematian, rasa sakit dan penderitaan. Liao et al, (2012) menyatakan diagnosis dan pengobatan kanker berdampak signifikan terhadap kesejahteraan fisik, psikologis, dan sosial, terutama pada pasien kanker yang mendapatkan pengobatan kemoterapi.

Kemoterapi ialah salah satu pengobatan untuk menghambat pertumbuhan sel kanker (National Cancer Institute, 2017). Ada 3 jenis kemoterapi yaitu adjuvant, neoadjuvant, dan primer (paliatif). Hasil penelitian Wahyuni, Huda, dan Utami (2015) didapatkan beberapa efek samping dari 3 jenis kemoterapi tersebut umumnya dirasakan pasien diantaranya fatigue. Penderita kanker sangat rentan terhadap fatigue akibat kelelahan fisik dan mental yang disebabkan oleh proses terapi yang panjang seperti kemoterapi yang didapatkan secara terus menerus (Nugroho \& Anggorowati, 2017). National Comprehensive Cancer Network (2014) menyatakan cancer-related 
fatigue adalah suatu kondisi subjektif berupa perasaan lelah terus menerus yang berhubungan dengan kanker atau pengobatannya. Cancer-related fatigue memberikan dampak terganggunya fungsi dan aktivitas sehari-hari pada pasien kanker post kemoterapi.

Fata (2015) menyatakan bahwa pasien kanker post kemoterapi merasa tidak nyaman akibat mual muntah, anemia, dan masalah tidur sehingga mengakibatkan fatigue. Pengkajian harus dilakukan pada pasien kanker post kemoterapi yaitu mengenai derajat fatiguenya. Fatigue pada pasien kanker post kemoterapi dapat diklasifikasikan berdasarkan derajat keparahannya yaitu berat, sedang dan ringan. Pengkajian fatigue biasanya mengenai perasaan lemah, ketidakmampuan untuk melakukan tugas, motivasi menurun dan suasana hati yang rendah, serta kesulitan dalam berpikir jernih (Strebkova, Petkova, \& Minev, 2017).

Pengkajian fatigue pada pasien kanker harus dilakukan secara multidisiplin dengan cara menyaring, menilai, dan mengelola data sehingga dapat mengidentifikasi dan mengeskplorasi derajat fatigue serta faktor-faktor yang dapat meningkatkan derjat fatigue pada pasien kanker post kemoterapi. Tujuan pengkajian tersebut untuk meningkatkan pemberian pengobatan dan perawatan dalam mengatasi fatigue post kemoterapi. Selain itu, hasil pengkajian derajat fatigue post kemoterapi penting untuk memberikan rekomendasi bagi praktisi (Alberta Health Services, 2017).

Hasil studi pendahuluan yang dilakukan 11 Desember 2018 di Poli Seruni RSUD Arifin Achmad Pekanbaru, didapatkan hasil wawancara 10 pasien kanker post kemoterapi di Poli Seruni didapatkan 5 pasien yang mengatakan sering mengalami kelelahan berupa merasa terganggu dalam menyelesaikan tugas atau pekerjaan. Hasil wawancara tersebut juga didapatkan bahwa 3 pasien kanker post kemoterapi mengatakan, tidak merasa puas terhadap istirahat maupun tidur, dan merasa tidak memiliki energi yang cukup, serta 2 pasien mengatakan sering mengalami gangguan tidur, sering merasa kebingungan atau tidak fokus terhadap pemikirannya sendiri, dan merasa kelelahan 
Dahlia $^{1}$, Darwin Karim ${ }^{2}$, dan Siti Rahmalia Hairani Damanik ${ }^{\mathbf{3}}$, Gambaran Fatigue pada Pasien Kanker Post Kemoterapi

meskipun tidak melakukan aktivitas. purposive sampling dengan 144 Responden.

Berdasarkan fenomena tersebut peneliti Alat pengumpul data dalam penelitian tertarik melakukan penelitian tentang ini terdiri dua bagian. Bagian pertama adalah gambaran fatigue pada pasien kanker post kuisioner mengenai data demografi pasien. kemoterapi.

Bagian kedua untuk mengidentifikasi derajat

Tujuan dari penelitian ini adalah untuk mengidentifikasi derajat fatigue pada pasien kanker post kemoterapi. Hasil penelitian ini diharapkan menjadi sumber informasi mengenai fatigue pada pasien kanker yang mendapatkan kemoterapi sehingga dapat diterapkan perawat sebagai panduan dalam melakukan pengkajian untuk mengidentifikasi derajat fatigue pada pasien kanker post kemoterapi.

fatigue pasien kanker post kemoterapi dengan menggunakan Piper Fatigue Scale.

Analisis data yang digunakan yaitu Analisis univariat menampilkan distribusi frekuensi dan persentase dari karakteristik responden meliputi usia, jenis kelamin, pendidikan terakhir, pekerjaan, stadium kanker, siklus kemoterapi, lama menderita kanker, diagnosa medis dan fatigue pada pasien kanker post kemoterapi.

\section{HASIL PENELITIAN}

\section{METODE PENELITIAN}

Penelitian dilakukan RSUD Arifin

Achmad Provinsi Riau dimulai bulan Februari 2019 sampai Juli 2019. Penelitian ini menggunakan desain penelitian deskriptif sederhana. Populasi dalam penelitian ini adalah seluruh pasien kanker yang menjalankan pengobatan kemoterapi dari 14 Februari sampai 13 Maret 2019 sebanyak 225 pasien. Pengambilan sampel menggunakan teknik

Hasil penelitian melaporkan hasil pengolahan data yang dapat dijelaskan baik dalam bentuk tabel, foto, gambar dan diagram.

\section{Karakteristik responden}

Tabel 1

Distribusi Frekuensi Data Berdasarkan Karakteristik Responden.

\begin{tabular}{lcc}
\hline $\begin{array}{l}\text { Karakteristik } \\
\text { responden }\end{array}$ & $\mathrm{N}$ & $\%$ \\
\hline Usia & & \\
\hline $21-25$ th $\quad$ (Dewasa & 28 & 19.4 \\
awal) & &
\end{tabular}


Jurnal Ners Indonesia, Vol.10 No.1, September 2019

\begin{tabular}{|c|c|c|}
\hline $\begin{array}{l}\text { Karakteristik } \\
\text { responden }\end{array}$ & $\mathrm{N}$ & $\%$ \\
\hline \multicolumn{3}{|l|}{ Usia } \\
\hline $\begin{array}{l}26-45 \text { th (Dewasa } \\
\text { akhir) }\end{array}$ & 49 & 34 \\
\hline $\begin{array}{l}\text { 46-55 th (Lansia } \\
\text { awal) }\end{array}$ & 47 & 32.6 \\
\hline $\begin{array}{l}56-65 \text { th (Lansia } \\
\text { akhir) }\end{array}$ & 20 & 13.9 \\
\hline \multicolumn{3}{|l|}{ Jenis kelamin } \\
\hline Laki-laki & 19 & 13.2 \\
\hline Perempuan & 125 & 86.8 \\
\hline \multicolumn{3}{|l|}{ Pendidikan terakhir } \\
\hline Tidak tamat SD & 2 & 1.4 \\
\hline $\mathrm{SD}$ & 40 & 27.8 \\
\hline SMP & 30 & 20.8 \\
\hline SMA & 46 & 31.9 \\
\hline Akademi/PT & 26 & 18.1 \\
\hline \multicolumn{3}{|l|}{ Pekerjaan } \\
\hline PNS & 6 & 4.2 \\
\hline Wiraswasta & 28 & 19.4 \\
\hline Ibu rumah tangga & 94 & 65.3 \\
\hline Petani & 11 & 7.6 \\
\hline Sopir & 5 & 3.5 \\
\hline \multicolumn{3}{|l|}{ Stadium kanker } \\
\hline Stadium 1 & 6 & 4.2 \\
\hline Stadium 2 & 48 & 33.3 \\
\hline Stadium 3 & 59 & 41 \\
\hline Stadium 4 & 31 & 21.5 \\
\hline \multicolumn{3}{|l|}{ Siklus kemoterapi } \\
\hline Siklus 1 & 8 & 5.6 \\
\hline Siklus 2 & 30 & 20.8 \\
\hline Siklus 3 & 22 & 15.3 \\
\hline Siklus 4 & 27 & 18.8 \\
\hline Siklus 5 & 19 & 13.2 \\
\hline Siklus 6 & 38 & 26.4 \\
\hline
\end{tabular}

\begin{tabular}{lcc}
\hline $\begin{array}{l}\text { Karakteristik } \\
\text { responden }\end{array}$ & $\mathrm{N}$ & $\%$ \\
\hline Usia & 74 & 51.4 \\
1-2 Tahun & 27 & 18.8 \\
3-4 Tahun & 16 & 11.1 \\
\hline 5 Tahun & & \\
\hline Diagnosa medis & 96 & 66.7 \\
\hline Ca. Mamae & 15 & 10.4 \\
Ca. Servik & 9 & 6.3 \\
Ca. Nasofaring & 4 & 2.8 \\
Ca. Lidah & 13 & 9 \\
Limfoma & 5 & 3.5 \\
Ca. Colon & 2 & 1.4 \\
Ca. Prostat & $\mathbf{1 4 4}$ & $\mathbf{1 0 0}$ \\
\hline Total &
\end{tabular}

Tabel 1 didapatkan bahwa mayoritas responden berusia 26-45 tahun (dewasa akhir) sebanyak 49 responden (34\%) dengan jenis kelamin perempuan sebanyak 125 orang $(86,8 \%)$. Sebagian besar responden pendidikan terakhir SMA sebanyak 46 orang $(31,9 \%)$ dengan pekerjaan paling banyak Ibu rumah tangga $\begin{array}{lll}\text { sebanyak } 94 \text { orang } & (65,3 \%) \text {. Stadium }\end{array}$ kanker mayoritas stadium 3 sebanyak 59 orang $(41 \%)$ dan responden sedang menjalani siklus kemoterapi 6 sebanyak 38 orang $(26,4 \%)$. Penderita kanker sudah mengatami selama 1-2 tahun sebanyak 74 orang $(51,4 \%)$ dengan diagnosa medis 
Dahlia $^{1}$, Darwin Karim ${ }^{2}$, dan Siti Rahmalia Hairani Damanik ${ }^{\mathbf{3}}$, Gambaran Fatigue pada Pasien Kanker Post Kemoterapi

terbanyak Ca. Mamae sebanyak 96 orang $(66,7 \%)$

2. Gambaran fatigue pada pasien kanker post kemoterapi

Tabel 2

Distribusi Frekuensi Fatigue pada Pasien Kanker Post Kemoterapi

\begin{tabular}{llcc}
\hline No & Fatigue & $\mathrm{N}$ & $\%$ \\
\hline 1. & Ringan & 11 & 7.6 \\
2. & Sedang & 72 & 50 \\
3. & Berat & 61 & 42.4 \\
\hline & Total & 144 & 100 \\
\hline
\end{tabular}

Tabel 2 didapatkan mayoritas responden yang menjalani kemoterapi mengalami fatigue tingkat sedang sebanyak 72 orang $(50 \%)$ dan diikuti tingkat berat sebanyak 61 orang $(42,4 \%)$ dan hanya sedikit mengalami tingkat ringan sebanyak 11 orang $(7,6 \%)$.

\section{PEMBAHASAN}

a. Usia

Hasil penelitian responden menunjukkan bahwa kelompok umur yang paling banyak yaitu 26-45 tahun (Dewasa akhir) sebanyak 49 (34\%). Kemenkes RI (2015) menyatakan bahwa kelompok umur 25-34 tahun, 35-44 tahun, dan 45-54 tahun merupakan kelompok umur dengan prevalensi kanker yang cukup tinggi. Peningkatan usia menyebabkan penurunan imunitas, penurunan perbaikan DNA dan menyebabkan hilangnya regulasi sel yang memfasilitasi terjadinya karsinogenesis dalam tubuh (Haryati, Bakriansyah dan Aisyah, 2013). Lanjut usia lebih sering terserang penyakit berisiko kesakitan meningkat seperti penyakit infeksi, kanker, kelainan autoimun, atau penyakit kronik. Hal ini disebabkan oleh perjalanan alamiah penyakit yang berkembang secara lambat dan gejala-gejalanya tidak terlihat sampai beberapa tahun kemudian (Fatma, 2006).

\section{b. Jenis Kelamin}

Mayoritas jenis kelamin responden adalah perempuan berjumlah 125 orang (86,8\%). World health organization (2018) menyatakan kejadian kanker dan kematian akibat kanker diperkirakan telah meningkat pada perempuan, kanker payudara merupakan penyebab utama 
kematian akibat kanker pada perempuan $(15 \%)$.

Perempuan adalah penderita kanker payudara terbanyak di seluruh dunia. Hal ini disebabkan oleh faktor genetik, diet tinggi lemak, obesitas, menarche di usia dini, menopause di usia tua, penggunaan hormon untuk pencegahan kehamilan, tidak memiliki anak juga merupakan faktor risiko, penggunaan terapi penggantian hormon dan aktivitas fisik yang kurang serta mengkonsumsi alkohol (Ghoncheh, Pournamdar, \& Salehiniya, 2016).

\section{c. Pendidikan terakhir}

Hasil penelitian sebagian besar pendidikan terakhir responden SMA sebanyak 46 orang $(31,9 \%)$. Pendidikan dapat mempengaruhi pengetahuan seseorang. Selain itu tingkat pendidikan seseorang akan mempengaruhi dalam penerimaan informasi mengenai penyakit kanker, baik mengenai faktor resiko yang dapat memicu, upaya apa saja yang dapat dilakukan untuk mencegahnya maupun cara deteksi dini serta memahami pengobatan penyakit kanker. Seseorang yang hanya sampai pendidikan menengah atau lulusan SMA sudah mampu menerima informasi dengan baik serta mengaplikasikannya. Notoadmodjo (2012) mengatakan dimana tingkat pendidikan merupakan indikator bahwa seseorang telah menempuh pendidikan formal dibidang tertentu namun bukan indikator bahwa seorang telah menguasai bidang ilmu. Pendidikan pada umumnya berguna untuk merubah pola pikir, pola bertingkah laku dan pola pengambilan keputusan.

\section{d. Pekerjaan}

Hasil penelitian sebagian besar responden Ibu rumah tangga sebanyak 94 orang (65,3\%). Ibu Rumah Tangga (IRT) melakukan kegiatan rutin setiap harinya seperti memasak, mencuci dan membersihkan rumah, tetapi setelah semua kegiatan selesai sisa waktu yang ada cenderung digunakan untuk bersantai dan tidur siang. Kebiasaan yang tidak baik dan aktivitas yang terbatas dapat memicu berbagai penyakit. Kemenkes RI (2015) 
Dahlia $^{1}$, Darwin Karim ${ }^{2}$, dan Siti Rahmalia Hairani Damanik ${ }^{\mathbf{3}}$, Gambaran Fatigue pada Pasien Kanker Post Kemoterapi

menyatakan bahwa salah satu faktor resiko penyakit kanker ialah kurang aktivitas fisik. Indriati (2005) menjelaskan bahwa aktivitas fisik atau berolahraga yang cukup akan berpengaruh terhadap penurunan sirkulasi hormonal sehingga menurunkan proses proliferasi dan mencegah kanker.

Selain itu, IRT sebagian besar menggunakan kontrasepsi hormonal berupa suntik KB. Sejalan dengan teori lain mengatakan kontrasepsi hormonal bertindak atas sel-sel lain dan membuat berkembang biak lebih cepat, mempercepat dan meningkatkan produksi sel kanker mutan yang ada (Maurer Foundation, 2012).

\section{e. Stadium kanker}

Stadium kanker mayoritas stadium III yaitu 59 orang (41\%). Hal ini disebabkan kanker stadium dini sering tidak disadari oleh pasien, karena gejala pada stadium dini sering tidak ditemukan sehingga pasien kanker yang datang berobat sudah berada pada stadium II dan
III (Hardiano \& Nurul, 2015). Selain itu, pasien kanker sebelum memeriksakan kondisinya mereka terlebih dahulu berobat ke pengobatan alternative. Hal ini tidak membuat ada perubahan terhadap kondisi mereka setelah berobat di pengobatan alternatif, namun setelah ada komplikasi atau tanda mengganggu kesehatan baru mereka berobat ke medis. Hal ini sesuai dengan responden menggunakan obat herbal dari cina. Penanganan secara medis menjadi terlambat dan memungkinkan pasien kanker dalam kondisi yang lebih parah (Septilia, Karim \& Huda ,2018).

\section{f. Siklus kemoterapi}

Siklus kemoterapi mayoritas kemoterapi 6 dari siklus 1-6 yaitu sebanyak 38 orang $(26,4 \%)$. Siklus kemoterapi 6 merupakan tahap akhir dari pengobatan kemoterapi yang dimulai dari siklus 1 dan berakhir pada siklus ke 6 . Pengobatan kemoterapi diberikan berdasarkan jenis dan stadium kanker dengan prinsip meracuni atau membunuh sel-sel kanker, mengontrol pertumbuhan 
sel kanker, dan menghentikan pertumbuhannya. Dengan demikian, diharapkan sel-sel kanker tidak menyebar ke bagian tubuh yang lain (American Cancer Society, 2016).

\section{g. Lama menderita kanker}

Sebagian besar pasien kanker terdiagnosa selama 1-2 tahun sebanyak 74 orang $(51,4 \%)$. Pasien kanker terdiagnosa selama 1-2 tahun disebabkan pasien mengatakan bahwa pasien sering tidak menyadari gejala awal penyakit kanker. Hal ini menyebabkan pasien yang datang berobat ke medis sudah stadium lanjut. Keadaan tersebut sangat sulit bagi pasien untuk dapat menerima dirinya sebagai orang yang sakit. Pasien merasakan kecemasan dan kesedihan yang terus menerus, murung, menderita sampai timbul ide atau perilaku pesimistis untuk berobat (Ningsih, 2015).

Kecemasan pada seseorang penderita kanker sering muncul tidak saja sewaktu penderita diberitahu mengenai penyakitnya, tetapi juga sedang menjalani pengobatan seperti kemoterapi.
Kecemasan tersebut biasanya menyangkut finansial, kekhawatiran tidak diterima dilingkungan keluarga atau masyarakat dan takut akan kematian akibat penyakit kanker serta efek samping dari pengobatan kemoterapi yang menyebabkan mual muntah, rambut rontok, nyeri tulang belakang, anemia dan lain-lain. Kashani, Vaziri, Akbari, Jamshidifar, dan Sanaei (2014) mengatakan meskipun kini pendeteksian kanker sudah berkembang dengan pesat, namun insidensi kanker merupakan stressor paling berpengaruh bagi penderitanya dan hal ini berhubungan terhadap persepsi masyarakat mengenai penyakit kanker yang identik dengan kematian, rasa sakit dan penderitaan. Hal tersebut mengakibatkan distress yang dapat memperparah kondisi penderita kanker sehingga semakin lama seseorang menderita kanker semakin jelek kondisinya (American Cancer Society, 2018)

\section{h. Diagnosa medis}

Mayoritas pasien kanker terdiagnosa 
Dahlia $^{1}$, Darwin Karim ${ }^{2}$, dan Siti Rahmalia Hairani Damanik ${ }^{\mathbf{3}}$, Gambaran Fatigue pada Pasien Kanker Post Kemoterapi

medis Ca. Mamae sebanyak 96 orang (66,7\%). Hal ini dikarenakan ada beberapa faktor risiko yang dapat menyebabkan pertumbuhan kanker payudara seperti sering mengonsumsi makanan berlemak, kebiasaan mengonsumsi makanan dibakar atau dipanggang serta sering mengonsumsi makanan berpengawet dan cepat saji sehingga dapat memicu sel kanker. Selain itu, obesitas dan kurang aktivitas dapat juga menyebabkan kanker payudara. Faktor lain penggunaan kontrasepsi oral dan terapi penggantian hormon (yang mencakup estrogen dan progesteron) dapat meningkatkan resiko kanker payudara (Breast Cancer, 2019).

Kemenkes RI (2015) mengatakan bahwa kanker payudara menempati urutan sebagai penyebab kelima kematian akibat kanker secara keseluruhan $\quad(522.000$ kematian). Prevalensi kanker payudara di Indonesia pada tahun 2013 sebesar 0,5\% atau diperkirakan sekitar 61.682 orang sedangkan provinsi Riau memiliki prevalensi penyakit kanker payudara yaitu sebesar $0,3 \%$ yaitu 894 orang.

\section{i. Fatigue pada pasien kanker post} kemoterapi

Hasil penelitian menggambarkan mayoritas responden pasien kanker mengalami fatigue post kemoterapi yaitu tingkat sedang sebanyak 72 orang $(50 \%)$. Namun demikian penelitian ini juga menemukan 61 orang $(42,2 \%)$ responden mengalami fatigue post kemoterapi yaitu tingkat berat. Penelitian ini sejalan dengan penelitian Nugroho dan Anggorowati (2017) menyatakan sebagian besar responden kanker mengalami fatigue sedang, yaitu sebanyak 28 orang $(52,8 \%)$. Penderita kanker sangat rentan terhadap fatigue dikarenakan rejimen dari pengobatan kanker yang didapatkan secara terus menerus. Fatigue terkait kanker merupakan kelelahan yang di ungkapkan pasien kanker bersifat menetap dan tidur tidak membuatnya membaik. Faktor yang menunjukkan penderita kanker mengalami fatigue disebabkan 
karena efek samping kemoterapi.

Kemoterapi dapat menyebabkan mual muntah, anemia dan mukositis (National Cancer Institute, 2015).

Mual muntah mengakibatkan kurangnya intake nutrisi ke dalam tubuh sehingga nutrisi ke sel pun berkurang. Sel-sel tubuh akan memecahkan lemak yang ada ditubuh untuh menghasilkan energi. Pemecahan asam lemak bebas dari jaringan lemak adiposa akan menyebabkan penumpukan keton didalam tubuh. Perubahan metabolisme tersebut menyebabkan penurunan metabolisme atau gangguan dalam regenerasi ATP, yang mana ATP adalah sumber energi utama untuk kontraksi otot-tulang. Hal ini menyebabkan kelelahan atau fatigue dan menurunkan kemampuan fisik pada pasien kanker (Ryan et al, 2007).

Selain itu anemia juga penyebab paling sering pemicu fatigue pada pasien kanker. Anemia disebabkan karena efek samping kemoterapi yang menghancurkan banyak sel darah merah sehat. Kanker juga bisa menyebar ke sumsum tulang belakang dan mengganggu produksi sel darah sehingga menyebabkan kurangnya sel darah merah (Mayo Foundation for Medical Education and Research, 2019). Hal ini membuat tubuh merasa sangat lelah karena sel-sel di tubuh tidak bisa mendapatkan cukup oksigen dan nutrisi sehingga tidak menghasilkan energi (ACS, 2018).

Faktor lain yang dapat memicu fatigue pada pasien kanker adalah gangguan jalan masuknya nutrisi ke tubuh karena perih akibat luka pada saluran pencernaan. Hal ini diakibatkan oleh efek samping kemoterapi yaitu mukositis. Mukositis dapat menyebabkan infeksi sekunder, asupan nutrisi yang buruk, dehidrasi sehingga juga bisa berkontribusi terhadap fatigue. (Junaidi, 2014; Sudoyo dkk, 2010)

Efek kemoterapi juga menyebabkan adanya pelepasan zat-zat sitokin seperti TNF (tumor nekrosis faktor) dan interleukin yang menyebabkan anoreksia. Anoreksia disebabkan karena sitokin seperti interleukin-1 (IL-1) dan tumor 
Dahlia $^{1}$, Darwin Karim ${ }^{2}$, dan Siti Rahmalia Hairani Damanik ${ }^{\mathbf{3}}$, Gambaran Fatigue pada Pasien Kanker Post Kemoterapi

necrosis factor-a (TNF) yang merupakan neurotransmiter yang menekan sistem saraf pusat pemicu penurunan nafsu makan. Hal ini menyebabkan penurunan berat badan dan massa otot serta anemia sehingga pasien kanker dengan stadium lanjut cenderung mengalami kelelahan (Argiles, Busquets, \& Lopez-Soriano, 2006).

Usia juga berpengaruh terhadap peningkatan fatigue yang di alami penderita kanker. Fobair et al (1986 dalam Narayanan \& Koshy 2009) menyatakan usia dianggap sebagai salah satu faktor prediktif yang menyebabkan terjadinya cancer-related fatigue, artinya semakin tua umur seseorang maka semakin berisiko mengalaminya, yang mana pasien berusia 34 tahun atau lebih rentan terhadap cancer-related fatigue dibanding usia yang muda.

\section{SIMPULAN}

Berdasarkan hasil penelitian menunjukkan bahwa karakteristik responden yang terdiri dari 144 responden didapatkan hasil mayoritas responden berusia 26-45 Tahun (Dewasa akhir), jenis kelamin perempuan, pendidikan terakhir SMA, pekerjaan ibu rumah tangga, stadium 3, siklus 6, lama menderita kanker selama 1-2 tahun dan Ca. Mamae. Berdasarkan fatigue yang dirasakan pasien post kemoterapi mayoritas responden tingkat sedang, yang diikuti tingkat berat dan tingkat ringan.

\section{SARAN}

Hasil penelitian ini diharapkan dapat dijadikan referensi penelitian lebih dalam lagi untuk peneliti selanjutnya tentang faktor-faktor yang mempengaruhi fatigue pada pasien kanker post kemoterapi.

\section{DAFTAR PUSTAKA}

Alberta Health Services. (2017). Cancer-related fatigue. Diperoleh 05 November 2018 dari https://www.alberta healthservices.ca

American cancer Society. (2016). Cancer Treatment \& Survivorship Facts \& Figures. Diperoleh 24 Oktober 2018 dari https://www.cancer.org.

American cancer Society. (2018a). Cancer Facts \& Figures. Diperoleh 15 Oktober 
2018 dari https://www.cancer.org

American cancer Society. (2018b). What Is

Cancer-related Fatigue?. Diperoleh 21

November 2018 dari https://www.cancer. org

Argiles, J. M., Busquets, S., \& Lopez, S. F. J. (2006). Cytokines as mediators and targets for cancer cachexia. In The Link Between Inflammation and Cancer,199-217.

Breast cancer. (2019). What can cause breast cancer?. Diperoleh 30 Mei 2019 dari https://breastcancernow.org

Depkes RI. (2009). Profil Kesehatan Indonesia. Diperoleh 22 Juni 2019 dari http://www.depkes.go.id

Fatma. (2006). Respons imunitas yang rendah pada tubuh manusia usia lanjut. Makara Kesehatan, 10(1), 47-53.

Ghoncheh, M., Pournamdar, Z., \& Salehiniya, H. (2016). Incidence and mortality and epidemiology of breast cancer in the world. Asian Pac J Cancer Prev, 17(S3), 43-46.

Hardiano, R., \& Nurul, H. (2015). Gambaran indeks massa tubuh pada pasien kanker yang mengalami kemoterapi. Jurnal Online Mahasiswa, 2(2), 1381-1388. Diperoleh 18 Mei 2019 dari https://media.neliti.com

Indrati, R. (2005). Faktor-faktor risiko yang berpengaruhi terhadap kejadian kanker payudara wanita. Diperoleh 21 Juni 2019 dari http://eprints.undip.ac.id.

Kashani, F. L., Vaziri, S., Akbari, M. E., Jamshidifar, Z., \& Sanaei, H. (2014). Stress Coping Skills Training and Distress in Women with Breast Cancer. Procedia - Social and Behavioral
Sciences, 159(23), 192-196.

Kementerian Kesehatan RI Pusat Data dan Informasi Kesehatan. (2015). Stop Kanker. Infodatin-kanker. Diperoleh 15 Oktober 2018 dari http://www.depkes.go. id

Liao, M. N., Chen, S. C., Chen, S. C., Lin, Y. C., Hsu, Y. H., Hung, H. C., ... \& Jane, S. W. (2012). Changes and predictors of unmet supportive care needs in Taiwanese women with newly diagnosed breast cancer. In Oncology nursing forum, 39( 5), 380-389.

Maurer Foundation. (2012). Estrogen And Breast Cancer. Diperoleh 29 Mei 2019 dari https://www.maurerfoundation.org

Mayo Foundation for Medical Education and Research. (2019b). Cancer fatigue: why it occurs and how to cope. Diperoleh 21 Mei 2019 dari https://www.mayoclinic. org

Narayanan, V., \& Koshy, C. (2009). Fatigue in cancer: a review of literature. Indian journal of palliative care, 15(1), 19-25.

National Cancer Institute. (2015). Chemotherapy to treat cancer. Diperoleh $07 \quad$ Februari 2019 dari https://www.cancer.gov

National Cancer Institute. (2017a). Types of cancer treatment. Diperoleh 11 November 2018 dari https://www. cancer.gov

National Comprehensive Cancer Network. (2014). Cancer related fatigue clinical Practice guidelines in oncology. Diperoleh 21 November 2018 dari http/nccn.org

Ningsih, S. F. (2015). Efektivitas terapi emotional freedom technique (EFT) 
Dahlia $^{1}$, Darwin Karim ${ }^{2}$, dan Siti Rahmalia Hairani Damanik ${ }^{\mathbf{3}}$, Gambaran Fatigue pada Pasien Kanker Post Kemoterapi

terhadap kecemasan pasien kanker payudara stadium II dan III. Jurnal Online Mahasiswa, 2(2), 1501-1509. Diperoleh 18 Mei 2019 dari https://media.neliti.com

Notoatmodjo, S. (2012). Metodologi penelitian kesehatan. Jakarta: Rineka Cipta.

Nugroho, S. T., \& Anggorowati, A. J. (2017). Kualitas Tidur dan Fatigue pada Klien Cancer. Adi Husada Nursing Journal , 3(1), 88-92.

Pipper BF., Dibble SL., Dodd MJ., Weiss MC., Slaugther RE., \& Paul SM. (1998). The revised piper fatigue scale: psychometric evaluation in women with breast cancer. Oncol Nurs Forum, 25(4), 677-84.

Ryan, J. L., Carroll, J. K., Ryan, E. P., Mustian, K. M., Fiscella, K., \& Morrow, G. R. (2007). Mechanisms of cancer-related fatigue. The oncologist, 12(1), 22-34.

Septilia, F., Karim, D., \& Huda, N. (2018). Hubungan tingkat stres dengan kualitas hidup pasien kanker payudara pada berbagai tingkatan stadium. Jurnal Online Mahasiswa, 5(2), 597-605. Diperoleh18 Mei 2019 dari https://jom.unri.ac.id

Strebkova, R., Petkova, M., \& Minev, M. (2017). Assessment of cancer related fatigue. Trakia Journal of Sciences, 15(3), 238-243.

Wahyuni, D., Huda, N., \& Utami, G. T. (2015). Studi fenomenologi: Pengalaman pasien kanker stadium lanjut yang menjalani kemoterapi. Jurnal Online Mahasiswa, 2(2), 1041-1047.

WHO. (2018). Latest global cancer data: Cancer burden rises to 18.1 million new cases and 9.6 million cancer deaths in 2018. Diperoleh tanggal 15 Oktober 2018 dari http://www.who.int/cancer 